\title{
Water Quality and Isolation of Vibrio cholerae non-O1 from an Aquatic Environment
}

\author{
Hidekazu UCHIYAMA and Tatsuya TODOROKI \\ Department of Pubric Health, School of Hygienic Sciences, Kitasato University \\ Key words: Vibrio cholerae non-O1, Environmental microbacteria, Water \\ quality
}

\begin{abstract}
According to reports hitherto on the isolation of Vibrio cholerae non-01 from the environment, environmental conditions at the time of detection differ depending on whether isolation is from the sea or rivers.

We based this study on two rivers of differing water quality and studied the trend of a bacteria indicator to observe the conditions of existence of $V$. cholerae non-O1.

1) It was thought that $V$. cholerae non-O1 did not flow from the land or other areas of pollution but existed at those points in the river from which they were isolated.

2) The proportion of $V$. cholerae non-O1 isolated was higher for the river with a higher degree of water pollution and higher in areas of high pollution in both rivers.

3) In rivers with a low degree of pollution or having a small range in water quality, an increase in $\mathrm{Cl}^{-}$ and $\mathrm{PO}_{4}{ }^{3-}$ ions, or an increase in the number of bacteria grown on nutrient agar medium at $37^{\circ} \mathrm{C}$ for 24 hours appears to increase the frequency of isolation of $V$. cholerae non-O1.

4) Approximately $13 \%$ of the samples of isolated $V$. cholerae non-O1 exhibited the cholera enterotoxin strain.

\section{Introduction}

It has been reported that $V$. cholerae non-O1 is frequently isolated after outbreaks of $V$. cholerae $01^{11}$. Futhermore it is considered that both $V$. cholerae $\mathrm{O} 1$ and non- $\mathrm{O} 1$ can exist for prolonged periods according to the environmental conditions.

It has also been reported that it is highly probable that $V$. cholerae non-O1 exists as an aquatic bacterial flora $^{2)}$. That is, after contaminating a river, $V$. cholerae non-O1 is thought to be able to exist like bacterial flora in the aquatic environment, when it co-exists with other organisms. It is estimated that with infection of the human body by $V$. cholerae non-O1 there is also an included risk of infection and the danger of existence of $V$. cholerae $\mathrm{O} 1$ which is merely different in serotype from $V$. cholerae non-O1.

In general, water quality and the composition of living organisms in the river are used to observe a river's environmental conditions.

We examined the conditions for the isolation of $V$. cholerae non-O1 and the river's microbiological, physical and chemical constituents and investigated the relationship between the river's environmental factors and the conditions of existence for $V$. cholerae non-O1.
\end{abstract}

\footnotetext{
別刷請求先：（元228）神奈川県相模原市北里 1

$-15-1$ 北里大学衛生学部公衆衛生学

教室 内山 秀和
} 


\section{Materials and Methods}

1. Location and duration of survey: Figure 1 shows the four locations on the Sagami River and five locations on the Sakai River that were selected. Sagamihara city is situated between the rivers. The survey was carried out during six months from July to December, 1985, at each of the locations and the river water sampled five times at approximately monthly intervals. At each station samples of river water were taken from two places; one being the center of running water and the other being from still water at the edge of the river.

Near location 1 on the Sagami R., water is discharged from the Tsukui Dam. Location 2 is upsteream from a filtration plant's intake waterway flood gate. There is a camping ground on the river beach between locations 1 and 2. At locatin 3 the river is wide and fishing boats come and go. Upstream from this location very polluted the Hato R. flows in. At location 4 there is a filtration plant and a barge just upstream and, at high tide, the seawater flows back to this location.

The Sakai R. flows from the Lake Shiroyama reservoir but is joined with the inflow of domestic drainage directly below this and becomes very polluted. Location 5 is located on the river where the width is less than one meter and the water flow is low. At location 6 the lathering of soap suds is already prevalent. At location 7 the river flows through a city and is joined by much drainage. Around location 8 are many tall buildings and there are many suspended particles in the river. Location 9 is only $0.8 \mathrm{~km}$ from an estuary. We believe that all environmental features are covered by the locations on the two rivers mentioned in the foregoing script. This survey covers approximately $30 \mathrm{~km}$ of each river.

2. Water quality examination methods (physical and chemical tests): Air temperature was measured with a mercury thermometer. Water temperature was measured with a Pettenkoffer's Water-themomter. The degree of transparency was measured with a $30 \mathrm{~cm}$ transparency measuring device. The $\mathrm{pH}$ was measured by colorimetry. The amount of ammonia nitrogen $\left(\mathrm{NH}_{4}{ }^{+}\right)$was measured using Nessler method and phosphate ion $\left(\mathrm{PO}_{4}{ }^{3-}\right)$ was measured using the ammonium molybdate method. Dissolved oxygen (DO) was measured by electrode method. The above analyses were performed immediately after taking the water samples. In addition, a $2000 \mathrm{ml}$ portion of the sampled water was carried in polyethlene tank to our laboratory and examined. The sodium cation $\left(\mathrm{Na}^{+}\right)$and the chlorine anion $\left(\mathrm{Cl}^{-}\right)$were measured by using the selective electrode method and water hardness was determined by the EDTA method. Electrical conductivity (EC) was measured with an electrical conductivity meter and the salinity concentrations were measured using a rifractometer with a minimum scale of $1 \%$.

3. Bacteriological analyses: The water samples were carried to our laboratory and analysed within 4

Fig. 1. Location of sampling stations in the Sagami River and the Sakai River.

1. Ogura-hashi; 2. Shouwa-hashi; 3. Sagamiohohashi; 4. Kamikawa-hashi; 5. Shiroyama-sakaihashi; 6. Negisi-hashi; 7. Sakai-hashi; 8. Midorihashi; 9. Arayashiki-hashi.

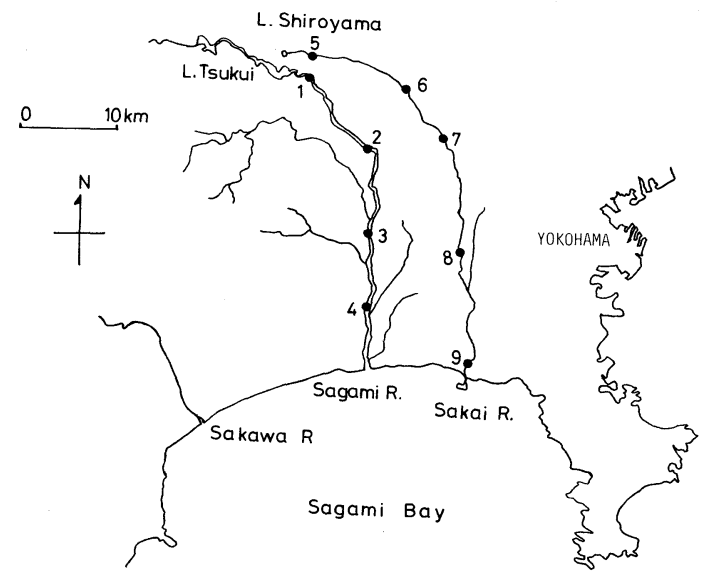

感染症学雑誌 第63巻 第 12 号 
Table 1 The identification of Vibrio cholerae non-O1

\begin{tabular}{|c|c|c|c|}
\hline Gram reaction & - & Oxidation-Fermentation (glucose) & $\mathrm{F}$ \\
\hline Shape & Rod & Glucose (gas) & - \\
\hline Spore & - & Lactose (acid) & \pm \\
\hline Motility & + & Sucrose (acid) & + \\
\hline Citrate utilization & + & Mannitol (acid) & - \\
\hline Gelatin hydrolysis & + & Inositol (acid) & - \\
\hline Urease & - & Arabinose (acid) & - \\
\hline Indol & + & Maltose (acid) & + \\
\hline $\mathrm{H}_{2} \mathrm{~S}$ & - & Salicin $\quad($ acid $)$ & - \\
\hline Lysine decarboxylase & + & Growth in $\mathrm{NaCl}$ (\% concentration) & \\
\hline Arginine dihydrolase & - & 0 & + \\
\hline Ornithine decarboxylase & + & 3 & + \\
\hline Voges-Proskauer & \pm & 7 & - \\
\hline Cytochrome-Oxidase & + & 10 & - \\
\hline Nitrate reduction & + & $0 / 129$ sensitivity & + \\
\hline Catalase & + & Anti-01 serm & - \\
\hline Oxdase & + & & \\
\hline
\end{tabular}

hours. Fecal coliform counts were estimated using a 3-tube replication of the most-probable-number series $(\mathrm{MPN})^{3)}$. The water samples were diluted with $0.85 \% \mathrm{NaCl}$ solution, then sprayed into a nutrient agar medium and cultivated for 24 hours at $37^{\circ} \mathrm{C}$. The total viable counts (TVC) were then determined by counting the number of colonies formed.

4. Isolation of $V$. cholerae non-01: The method followed for examining the $V$. cholerae was that of the Japanese society for bacteriology ${ }^{4)}$. Immediately after the river water had been sampled, $450 \mathrm{ml}$ was mixed with $50 \mathrm{ml}$ alkaline peptone medium and, after cultivating for six hours, a portion of the supernatant medium was tansferred to a non-salt alkaline peptone medium and the remainder streaked onto thiosulphate citrate bile salts agar medium (TCBS, Eiken). More than three colonies were picked up from the TCBS medium. The isolated strains are identified in Table 1.

5. Detection of cholera enterotoxin (CT) from V. cholerae non-O1: All strains isolated from the river water were incubated in Syncase medium and the cultivated medium was tested with reversed passive latex hemagglutination (Denka, VET-RPLA kit).

\section{Results}

It was expected that, because the environmental conditions of the Sagami R. and the Sakai R. differed, the water quality and composition of organisms would be different. Table 2 shows the range of TVC and coliform and the water quality ranges for each of the locations on the Sagami R. (locations 1-4) and on the Sakai R. (locations 5-9).

At the uppermost location of both rives, locations 1 and 5, the TVC counts were the lowest. At each of the downstream locations, the TVC counts for the Sagami R. ranged over $10^{3} \sim 10^{4} / \mathrm{ml}$, whereas the Sakai R. recorded a wider range of values with a lower limit of $10^{4} / \mathrm{ml}$ and upper limits of $10^{5}$ and $10^{6} / \mathrm{ml}$.

The number of coliform in the Sagami R. showed an uniform increase when going from upstream to downstream and had a range of $10^{2}$ to $10^{5} / 100 \mathrm{ml}$. However, for the Sakai R., the number of coliform showed a lower limit of $10^{4 / 100 ~} \mathrm{ml}$ and an upper limit of $10^{7} / 100 \mathrm{ml}$ at location 7 but decreased to $10^{6 / 100}$

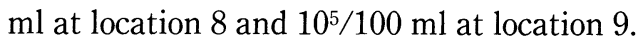

The values and ranges of the water quality parameters differed markedly between the two rivers. That is, on the Sagami R. the concentration of $\mathrm{Na}^{+}$and $\mathrm{Cl}^{-}$ions and water hardness increased when going downstream, especially at the lowest location, location 4. However, all locations recorded low values of 
Table 2 Range of varios environmental parameters at the location of the Sagami River and the Sakai River

\begin{tabular}{|c|c|c|c|c|c|c|c|c|c|c|c|c|}
\hline \multirow{2}{*}{$\begin{array}{c}\text { Loca- } \\
\text { tion }\end{array}$} & \multicolumn{2}{|c|}{ Microbiological parameter } & \multirow{2}{*}{$\underset{{ }^{\circ} \mathrm{C}}{\text { Temp. }}$} & \multirow{2}{*}{$\begin{array}{l}\text { W. temp. } \\
{ }^{\circ} \mathrm{C}\end{array}$} & \multirow[b]{2}{*}{$\mathrm{pH}$} & \multicolumn{7}{|c|}{ Water Quality parameter } \\
\hline & $\begin{array}{l}\mathrm{TVC} \\
/ \mathrm{ml}\end{array}$ & $\begin{array}{c}\text { Coliform } \\
\text { MPN } / 100 \mathrm{ml}\end{array}$ & & & & $\underset{\mathrm{mg} / l}{\mathrm{DO}}$ & $\begin{array}{c}\text { Hardness } \\
\mathrm{mg} / l\end{array}$ & $\underset{\mu \mathrm{S} / \mathrm{cm}}{\mathrm{E} . \mathrm{C} .}$ & $\begin{array}{l}\mathrm{Na}^{+} \\
\mathrm{mg} / l\end{array}$ & $\begin{array}{c}\mathrm{Cl}^{-} \\
\mathrm{mg} / l\end{array}$ & $\begin{array}{l}\mathrm{NH}_{4}^{+}+ \\
\mathrm{mg} / \mathrm{l}\end{array}$ & $\begin{array}{l}\mathrm{PO}_{4}{ }^{3-} \\
\mathrm{mg} / l\end{array}$ \\
\hline 1 & $\begin{array}{l}4.2 \times 10^{2} \\
-3.9 \times 10^{3 *}\end{array}$ & $\begin{array}{l}9.1 \times 10^{2} \\
\quad-2.1 \times 10^{4}\end{array}$ & $\stackrel{13.0}{\sim} 19.8$ & $\stackrel{13.4}{\sim 21.8}$ & $\stackrel{7.4}{\sim 8.4}$ & $\stackrel{5.5}{\sim 7.3}$ & $\stackrel{57.2}{\sim 66.4}$ & $\stackrel{185.5}{\sim 204.0}$ & $\stackrel{2.0}{\sim 10.0}$ & $\stackrel{4.8}{\sim 5.6}$ & $\stackrel{<0.1}{\sim 0.1}$ & $\begin{array}{r}<0.05 \\
\quad \sim 0.1\end{array}$ \\
\hline 2 & $\begin{array}{l}2.0 \times 10^{3} \\
-2.0 \times 10^{4}\end{array}$ & $\begin{array}{l}9.2 \times 10^{2} \\
\quad \sim 1.1 \times 10^{5}\end{array}$ & $\stackrel{19.0}{\sim} 30.0$ & $\stackrel{16.7}{\sim 21.2}$ & $\stackrel{7.2}{\sim 7.6}$ & $\stackrel{6.8}{\sim 7.7}$ & $\stackrel{30.8}{\sim 70.3}$ & $\begin{array}{l}104.5 \\
\sim 236.0\end{array}$ & $\stackrel{0.2}{\sim 20.5}$ & $\stackrel{5.2}{\sim 13.5}$ & $<\underset{\sim 2.0}{<2.1}$ & $\begin{array}{l}<0.05 \\
\sim 0.1\end{array}$ \\
\hline 3 & $\begin{array}{l}2.0 \times 10^{3} \\
-2.5 \times 10^{4}\end{array}$ & $\begin{array}{l}2.1 \times 10^{3} \\
\sim 1.1 \times 10^{5}\end{array}$ & $\stackrel{24.0}{\sim} 30.5$ & $\stackrel{17.0}{\sim 21.0}$ & $\stackrel{7.4}{\sim 7.6}$ & $\stackrel{6.4}{\sim 8.1}$ & $\begin{array}{l}50.6 \\
\sim 96.0\end{array}$ & $\stackrel{118.0}{\sim 249.0}$ & $\stackrel{0.6}{\sim 19.0}$ & $\stackrel{7.6}{\sim} 14.0$ & $\stackrel{<0.1}{\sim 1.0}$ & $\begin{array}{l}0.05 \\
\sim 0.1\end{array}$ \\
\hline 4 & $\begin{array}{l}1.3 \times 10^{3} \\
\sim 1.1 \times 10^{4}\end{array}$ & $\begin{array}{l}9.3 \times 10^{3} \\
\quad 2.4 \times 10^{5}\end{array}$ & $\stackrel{24.0}{\sim 29.5}$ & $\stackrel{16.6}{\sim 26.0}$ & $\stackrel{6.6}{\sim 7.4}$ & $\stackrel{4.4}{\sim 9.4}$ & $\begin{array}{l}61.6 \\
\sim 184.7\end{array}$ & $\stackrel{137.0}{\sim 419.0}$ & $\stackrel{19.0}{\sim 64.0}$ & $\stackrel{11.5}{\sim 29.0}$ & $<\underset{\sim 1.0}{\sim}$ & $\stackrel{0.05}{\sim 0.1}$ \\
\hline 5 & $\begin{array}{l}1.9 \times 10^{4} \\
\sim 2.4 \times 10^{5}\end{array}$ & $\begin{array}{l}9.3 \times 10^{4} \\
\sim 2.4 \times 10^{5}\end{array}$ & $\stackrel{15.0}{\sim} 22.2$ & $\stackrel{13.8}{\sim 18.8}$ & $\stackrel{6.4}{\sim 7.4}$ & $\stackrel{3.6}{\sim 4.6}$ & $\begin{array}{l}87.9 \\
\sim 91.6\end{array}$ & $\begin{array}{l}200.5 \\
\sim 324.5\end{array}$ & $\stackrel{38.0}{\sim 70.0}$ & $\stackrel{13.5}{\sim} 19.0$ & $<0.1$ & $\begin{array}{l}0.05 \\
\sim 0.3\end{array}$ \\
\hline 6 & $\begin{array}{l}5.8 \times 10^{4} \\
\sim 2.2 \times 10^{5}\end{array}$ & $\begin{array}{l}4.4 \times 10^{4} \\
\sim 2.4 \times 10^{6}\end{array}$ & $\stackrel{13.8}{\sim 24.5}$ & $\stackrel{14.0}{\sim} 20.4$ & $\stackrel{6.0}{\sim 7.4}$ & $\stackrel{3.2}{\sim 5.2}$ & $\begin{array}{l}109.9 \\
\sim 149.8\end{array}$ & $\stackrel{413.5}{\sim 1065}$ & $\stackrel{180}{\sim 970}$ & $\stackrel{39.0}{\sim} 154$ & $\stackrel{3.0}{\sim}>5.0$ & $\stackrel{0.5}{\sim 2.0}$ \\
\hline 7 & $\begin{array}{l}6.7 \times 10^{4} \\
\sim 1.8 \times 10^{6}\end{array}$ & $\begin{array}{l}2.9 \times 10^{4} \\
\sim 1.1 \times 10^{7}\end{array}$ & $\stackrel{8.0}{\sim} 30.0$ & $\stackrel{10.9}{\sim 26.2}$ & $\stackrel{6.2}{\sim 7.4}$ & $\stackrel{2.6}{\sim 5.0}$ & $\begin{array}{l}105.5 \\
\sim 127.5\end{array}$ & $\stackrel{359.5}{\sim 757.5}$ & $\stackrel{180}{\sim 420}$ & $\stackrel{41.0}{\sim 71.0}$ & $\stackrel{<0.1}{\sim}>5.0$ & $\stackrel{0.7}{\sim 3.0}$ \\
\hline 8 & $\begin{array}{l}6.4 \times 10^{4} \\
-1.4 \times 10^{6}\end{array}$ & $\begin{array}{l}2.1 \times 10^{4} \\
-2.4 \times 10^{6}\end{array}$ & $\stackrel{11.0}{\sim} 31.0$ & $\stackrel{12.0}{\sim 25.8}$ & $\stackrel{6.0}{\sim 7.4}$ & $\stackrel{4.1}{\sim 6.6}$ & $\stackrel{96.7}{\sim 116.5}$ & $\stackrel{355.0}{\sim 605.0}$ & $\stackrel{180}{\sim 305}$ & $\stackrel{47.0}{\sim 63.0}$ & $\stackrel{<0.1}{\sim}>5.0$ & $\stackrel{0.7}{\sim 5.0}$ \\
\hline 9 & $\begin{array}{l}4.2 \times 10^{4} \\
\sim 2.4 \times 10^{5}\end{array}$ & $\begin{array}{l}2.0 \times 10^{4} \\
\quad \sim 4.3 \times 10^{5}\end{array}$ & $\stackrel{9.0}{\sim 29.0}$ & $\stackrel{10.6}{\sim 25.4}$ & $\stackrel{6.8}{\sim 7.4}$ & $\stackrel{3.1}{\sim 6.2}$ & $\begin{array}{l}96.7 \\
\sim 145.1\end{array}$ & $\stackrel{372.0}{\sim 568.0}$ & $\stackrel{170}{\sim 280}$ & $\stackrel{44.5}{\sim 58.0}$ & $\stackrel{<0.1}{\sim}>5.0$ & $\stackrel{0.3}{\sim 2.0}$ \\
\hline
\end{tabular}

Abbreviation; TVC : total viable counts, Coliform : fecal coliform (most probable number)., Temp.: air temperature, W. temp. : water temperature., DO : dissolved oxygen., E.C. : electric conductivity., $\mathrm{Na}^{+}$: sodium ion., $\mathrm{Cl}^{-}$: chloride ion., $\mathrm{NH}_{4}^{+}$: ammonia nitrogen., $\mathrm{PO}_{4}{ }^{3-}$ : phosphate ion.

${ }^{*}$ minimam $\sim$ maximam range.

Table 3 Seasonal variation in Vibrio cholerae non-O1 was isolated at location 9

\begin{tabular}{rccccc}
\hline Date $^{1)}$ & $\begin{array}{c}\text { Point of } \\
\text { river }\end{array}$ & $\begin{array}{c}\text { Temp. } \\
{ }^{\circ} \mathrm{C}\end{array}$ & $\begin{array}{c}\text { W. temp. } \\
{ }^{\circ} \mathrm{C}\end{array}$ & $\begin{array}{c}\mathrm{TVC} \\
/ \mathrm{ml}\end{array}$ & $\begin{array}{c}\mathrm{Cl}^{-} \\
\mathrm{mg} / \mathrm{l}\end{array}$ \\
\hline $7 / 09$ & $\mathrm{C}^{2)}$ & 29.0 & 25.2 & $1.8 \times 10^{5}$ & 50.5 \\
$9 / 17$ & $\mathrm{~B}$ & 25.0 & 22.7 & $1.6 \times 10^{5}$ & 55.0 \\
$10 / 03$ & $\mathrm{C}$ & 26.0 & 21.8 & $5.2 \times 10^{4}$ & 55.5 \\
$11 / 01$ & $\mathrm{~B}$ & 19.0 & 17.3 & $1.9 \times 10^{5}$ & 45.5 \\
$12 / 03$ & $\mathrm{~N}$ & 9.0 & 10.6 & $4.5 \times 10^{4}$ & 55.5 \\
\hline
\end{tabular}

Abbreviation; 1) Date: sampling date, Point of river: Vibrio cholerae non-O1 was isolated from the point of river, Temp. : air temperature, W. temp. : water temperature, TVC: total viable count, $\mathrm{Cl}^{-}$: concentration of chloline ion, 2) $\mathrm{C}$ : center of river, $\mathrm{B}$ : both of center and edge of river, $\mathrm{N}$ : not isolated

$\mathrm{NH}_{4}{ }^{+}$and $\mathrm{PO}_{4}{ }^{3-}$. For the Sakai R., the lowerbounds of ion solute concentration recorded for each of the locations were almost constant, excluding the uppermost location 5, but the upper bounds recorded were larger depending on the location. When comparing the ion solute concentrations for both rivers, the Sakai R. showed a larger range than that shown for the Sagami R.. Although it is not shown in the table, the salinity concentrations at all locations had the low of value of $0 \sim 2 \%$, and the degree of transparency measured at locations $7,8,9$ on the Sakai R. was approximately $20 \sim 30 \mathrm{~cm}$ but at all other locations was greater than $30 \mathrm{~cm}$.

There was no difference in water temperature between the two rivers. In July the temperature was approximately $25^{\circ} \mathrm{C}$ and in winter, in December, it decreased to approximately $11^{\circ} \mathrm{C}$. This trend, typified by location 9 , is shown in table 3 with the values being calculated from the mean for each sample. As stated above, the range of values found for the water quality experiments and TVC and coliform tests was small, and the level of pollution increased when going from upstream to downstream. However, at each of the locations on the Sakai R. the degree of pollution differed and, compared with the Sagami R., the number of 
Table 4 Vibrio cholerae non-O1 was isolated from the point of river site and ratio of isoation

\begin{tabular}{|c|c|c|c|c|}
\hline \multirow{3}{*}{ River } & \multirow{3}{*}{ Location } & \multicolumn{3}{|c|}{ Ratio of isolation } \\
\hline & & \multicolumn{2}{|c|}{ The point of river site } & \multirow{2}{*}{ Location total } \\
\hline & & Edge & Center & \\
\hline \multirow[t]{5}{*}{ Sagami R. } & 1 & $0 / 3^{1)}$ & $0 / 3$ & $0 / 6$ \\
\hline & 2 & $1 / 4$ & $1 / 4$ & $2 / 8$ \\
\hline & 3 & $2 / 4$ & $4 / 4$ & $6 / 8$ \\
\hline & 4 & $3 / 4$ & $1 / 4$ & $4 / 8$ \\
\hline & total & $6 / 15$ & $6 / 15$ & $12 / 30$ \\
\hline \multirow[t]{6}{*}{ Sakai R. } & 5 & $\mathrm{ND}^{2)}$ & $0 / 3$ & $0 / 3$ \\
\hline & 6 & $2 / 3$ & $1 / 3$ & $3 / 6$ \\
\hline & 7 & $2 / 5$ & $2 / 5$ & $4 / 10$ \\
\hline & 8 & $1 / 5$ & $4 / 5$ & $5 / 10$ \\
\hline & 9 & $2 / 5$ & $4 / 5$ & $6 / 10$ \\
\hline & total & $7 / 18$ & $11 / 21$ & $18 / 39$ \\
\hline
\end{tabular}

1) number of isolated Vibrio cholerae non-O1/number of samples

2) ND: not done

Table 5 Environmental microbiology and water quality parameter with or without isolation of Vibrio cholerae non-O1 in the Sagami River and the Sakai River

\begin{tabular}{|c|c|c|c|c|c|c|c|c|c|c|}
\hline \multirow[b]{2}{*}{ River } & \multirow[b]{2}{*}{ isolation } & \multicolumn{2}{|c|}{ Microbiological Parameter ${ }^{1)}$} & \multicolumn{7}{|c|}{ Water Quality Parameter ${ }^{2)}$} \\
\hline & & $\underset{/ \mathrm{ml}}{\mathrm{TVC}}$ & $\begin{array}{c}\text { Coliform } \\
\mathrm{MPN} / 100 \mathrm{ml}\end{array}$ & $\mathrm{DO}$ & $\begin{array}{c}\text { hardness } \\
\mathrm{mg} / l\end{array}$ & $\underset{\mu \mathrm{S} / \mathrm{cm}}{\mathrm{E} . \mathrm{C}}$ & $\begin{array}{l}\mathrm{Na}^{+} \\
\mathrm{mg} / l\end{array}$ & $\begin{array}{c}\mathrm{Cl}^{-} \\
\mathrm{mg} / l\end{array}$ & $\begin{array}{l}\mathrm{NH}_{4}^{+} \\
\mathrm{mg} / l\end{array}$ & $\begin{array}{l}\mathrm{PO}_{4}{ }^{3-} \\
\mathrm{mg} / l\end{array}$ \\
\hline \multirow[t]{2}{*}{ Sagami } & with & $(1.1 \pm 0.7) \times 10^{4 *}$ & $(4.0 \pm 6.7) \times 10^{4}$ & $\begin{array}{l}6.7 \\
\pm 1.1\end{array}$ & $\begin{array}{l}83.5 \\
\pm 33.7\end{array}$ & $\begin{array}{l}220.5 \\
\pm 81.3\end{array}$ & $\begin{array}{l}21.1 \\
\pm 15.9\end{array}$ & $\begin{array}{l}14.0^{*} \\
\pm 5.6\end{array}$ & $\begin{array}{l}0.2 \\
\pm 0.3\end{array}$ & $\begin{array}{l}0.08^{*} \\
\pm 0.03\end{array}$ \\
\hline & without & $(5.4 \pm 5.4) \times 10^{3}$ & $(1.9 \pm 2.6) \times 10^{4}$ & $\begin{array}{l}7.1 \\
\pm 0.8\end{array}$ & $\begin{array}{l}66.9 \\
\pm 20.7\end{array}$ & $\begin{array}{l}195.8 \\
\pm 73.9\end{array}$ & $\begin{array}{l}12.1 \\
\pm 14.0\end{array}$ & $\begin{array}{l}8.5 \\
\pm 4.0\end{array}$ & $\begin{array}{l}0.2 \\
\pm 0.5\end{array}$ & $\begin{array}{l}0.05 \\
\pm 0.03\end{array}$ \\
\hline \multirow[t]{2}{*}{ Sakai } & with & $(3.0 \pm 3.2) \times 10^{5}$ & $(1.0 \pm 2.5) \times 10^{6}$ & $\begin{array}{l}4.7 \\
\pm 1.0\end{array}$ & $\begin{array}{l}116.8 \\
\quad \pm 13.9\end{array}$ & $\begin{array}{l}479.5 \\
\quad \pm 116.6\end{array}$ & $\begin{array}{l}260.8 \\
\quad \pm 63.4\end{array}$ & $\begin{array}{l}53.6 \\
\pm 7.3\end{array}$ & $\begin{array}{l}4.0 \\
\pm 2.2\end{array}$ & $\begin{array}{l}1.24 \\
\pm 0.65\end{array}$ \\
\hline & without & $(3.4 \pm 5.1) \times 10^{5}$ & $(6.7 \pm 11.1) \times 10^{5}$ & $\begin{array}{l}4.2 \\
\pm 1.0\end{array}$ & $\begin{array}{l}119.3 \\
\pm 17.0\end{array}$ & $\begin{array}{l}505.7 \\
\quad \pm 212.2\end{array}$ & $\begin{array}{l}274.4 \\
\quad \pm 185.9\end{array}$ & $\begin{array}{l}52.6 \\
\pm 27.1\end{array}$ & $\begin{array}{l}3.0 \\
\pm 2.4\end{array}$ & $\begin{array}{l}1.35 \\
\pm 1.11\end{array}$ \\
\hline
\end{tabular}

1) (mean \pm S.D.), 2) mean \pm S.D.,

Abbreviation; TVC : total viable counts, Coliform : fecal coliform (most probable number)., DO : dissolved oxygen., E.C. : electric conductivity., $\mathrm{Na}^{+}$: sodium ion., $\mathrm{Cl}^{-}$: chloride ion., $\mathrm{NH}_{4}^{+}$: ammonia nitrogen., $\mathrm{PO}_{4}$ : phosphates ion.

*statistic significance $(p<0.05)$

TVC and coliform were greater, as was the ion solute, indicating that the river was very polluted.

As shown in table 4, of the 69 water samples collected from both rivers during this survery, 30 (43.5\%) were isolated to contain $V$. cholerae non-O1. The percentage isolated for the Sagami R. was $40.0 \%(12 / 30)$ and that for the Sakai R. was $46.2 \%$ (18/39). V. cholerae non-O1 was not isolated at the uppermost locations of either rivers (locations 1 and 5), but for both rivers, the percentage isolated increased when going downstream. At location 7, 8, 9 on the Sakai R., when the water temperature was below $11^{\circ} \mathrm{C} \mathrm{V}$. cholerae non- $\mathrm{O} 1$ was not isolated at all but when the water temperature increased to above $11^{\circ} \mathrm{C}$ it was always isolated at locations 8 and 9 .

At each location (excluding the location 5 ) on the river the percentage isolated in running water at the center of river and in standing water at the river's edge was $51.5 \%(17 / 33)$ and $39.4 \%(13 / 33)$ respectively. There was no significant difference shown between the isolation of this organism in running water at the center of the river and isolation in standing water at edge of the river for either of the rivers. 
The samples of river water which were detected to contain $V$. choleare non-O1 (from locations $6,7,8$ of the Sakai R.) produced a CT strain with a ratio of $4 / 30(13.3 \%)$.

The microbiological and water quality parameters recorded from the water samples with and without isolation of $V$. cholerae non-O1 are shown in table 5. For the Sagami R. it was noted that TVC and the ion $\mathrm{Cl}^{-}$and $\mathrm{PO}_{4}{ }^{3-}$ were greater when $V$. cholerae non-O1 was detected. However, for the Sakai R., no difference was observed in the water quality parameters with or without isolation of $V$. cholerae non-O1. Although all the water quality parameters have higher values for the Sakai R. than those for the Sagami R. it does not necessarily follow that $V$. cholerae non-O1.

\section{Discussion}

The occurrence of $V$. cholerae $\mathrm{O} 1$ in rivers is sometimes reported but it is usually short-lived. However, $V$. cholerae non- 01 , which is of the same group as $\mathrm{O} 1$, can be isolated at the same time that $\mathrm{O} 1$ is prevalent and also after such outbreaks have occured ${ }^{15)}$. Furthermore, Colwell R.R. et al. interpreted that there was a possibility that Vibrio spp. can exist as bacteria in rivers and other aquatic environments ${ }^{6}$. That is, when $V$. cholerae non-O1 occurs, growth is possible, given the right environmental conditions, and it is possible that, through this polluted water and aquatic foods, people may become infected ${ }^{7}$. Reports on infection from aquatic foods and reports on isolation in environmental survery have focused on salinity concentrations ${ }^{819)}$. In the survey conducted at Chesapeake Bay, it was found that $V$. cholerae non-O1 can exist in concentrations of $4 \sim 17 \%$ salinity ${ }^{2}$ conversely, existence is also reported for clear rivers such as the Western Colorado R. which has an $\mathrm{Na}^{+}$concentration of less than $5 \mathrm{mM}^{10}$.

In our results for the Sagami R., the $\mathrm{Na}^{+}$concentration was about $20 \mathrm{mg} / 1\left(\mathrm{Na}^{+}\right.$concentration approx. 1 $\mathrm{mM}$ ) when $V$. cholerae non-O1 was isolated but there was no significant difference shown with $\mathrm{Na}^{+}$ concentration when not isolated although the results were slightly higher. At each location the salinity concentration was $0 \sim 2 \%$ (salinity of concentration $0.04 \sim 0.3 \%$ when converted to $\mathrm{Cl}^{-}$concentration) therefore we do not consider salinity concentrations to be a suitable indicator for the existence of $V$. cholerae non-01.

In this survey the rivers were, for comparison purposes, two of differing environments with many natural features, such as the characteristic water quality and composition of aquatic microbial flora, and we investigated the effect these had on the existence of $V$. cholerae non-O1 and from these results we considered that it may be possible for the water quality characteristics to be used for an indicator for showing existence.

It is usual for water samples from many different locations to be mixed together and examined, but in our investigation we individually examined the water samples taken from running water at the center of the river and from standing water at the edge of river for each of the locations. Our results showed a high frequency of isolation at the center of running water at several locations but there was no significant difference shown in the frequency of isolation between the center and edges. These results suggest that, not only does $V$. cholerae non-O1 flow in from polluted areas and float down fast flowing water, but also exists widely at each location.

It is repoted that the isolation of $V$. cholerae non-O1 changes seasonally and, in particular, is influneced by low temperatures ${ }^{11}$. At location 7, 8 and 9 , of the five times surveyed, excluding the time in December when the water temperature was below $11^{\circ} \mathrm{C}$, isolation occurred at either the center or the edge of the river at each of these locations (in July no isolation at location 7). However, when the water temperature dropped to $11^{\circ} \mathrm{C} \mathrm{V}$. cholerae non- $\mathrm{O} 1$ was not isolated from any of the water samples. As it can be seen from the results for location 9 (Table 3) a decrease was shown for TVC but there was no observed change in the water quality, so we believe the reason why isolation did not occur below $11^{\circ} \mathrm{C}$ was because of the effect of 
the drop in temperature.

For the Sakai R., excluding the samples that were influenced by low water temperatures (under $11^{\circ} \mathrm{C}$ ) duing the winter season, the isolation rate was $50 \%(4 / 8)$ at location $7,62.5 \%(5 / 8)$ at location $8,75 \%(6 / 8)$ at location 9 and the isolation rate for all the samples taken from the Sakai R. was $54.5 \%$. When compared with the Sagami R. the isolation rate was higher, even when disregarding the effect of fall in tempeature. Furthermore, as the level of pollution increased when going downstream, the rate of isolation of this organism also increased for both rivers. This indicates that higher pollution levels make existence of $V$. cholerae non-01 possible.

$V$. cholerae non-O1 was not detected at all throughout the period of the survey at locations 1 and 5 . Both these locations were situated at the uppermost part of the rivers where the pollution levels for both rivers were the lowest. Even at location 5 on the Sakai R. where the width was less than 1 meter, the water volume extremely small and the level of pollution higher than that for the Sagami R. $V$. cholerae non-O1 was not isolated. It is assumed that this was because at this uppermost location there was no scattering of this organism caused by the tide flowing upstream and the inflow of polluted water was also small, but it may be assumed that, because of the level of pollution.

$V$. cholerae non-O1 may exist in the future. However at present, even if this organism were to occur, it is very unlikely to exist because of some other primary factor. That is, different microbial flora in differing water qualities at each location and in each river interact with $V$. cholerae non-O1 ${ }^{12}$ ) and thus it is considered that this has an effect on the existence of this organism.

For the Sagami R. isolation of $V$. choleare non-O1 was significant when the TVC counts were high and when the concentrations of $\mathrm{Cl}^{-}$and $\mathrm{PO}_{4}{ }^{3-}$ were high. Correlation was shown between $\mathrm{Cl}^{-}$and $\mathrm{Na}^{+}$, and $\mathrm{Cl}^{-}$ and $\mathrm{EC}$, but the values for $\mathrm{Na}^{+}$and $\mathrm{EC}$ were spread over a wide range and a statistical difference, like that found for $\mathrm{Cl}^{-}$was not shown. This suggests that $\mathrm{Cl}^{-}$is a better indicator for the isolation of $V$. cholerae non-O1.

According to Hood M.A. et al. the isolation of $V$. cholerae non-O1 is not necessarily correlated to coliform ${ }^{13)}$, which is used as an indicator in aquatic environments contaminated with human and animal feces, so it cannot be used as an indicator for the isolation of $V$. cholerae non-O1 and thus this organism does not derive from human and animal feces. In our survey we also found the relation between coliform and $V$. choleare non-O1 to be unclear so this suggested that $V$. cholerae non-O1 did not derive from human and animal feces.

In this survey the sampled river water was transported at room temperature (about $20^{\circ} \mathrm{C}$ ). Within 4 hours of sampling, the water was examined and thus the mutual effects on the bacteria in the water were considered to be small but in the future the effects of other organisms and solutes should be considered.

In the past $V$. cholerae $\mathrm{O} 1$ has occurred in the Sagami R. ${ }^{14)}$. Therefore it is quite logical to think that it is also possible for $V$. cholerae non-O1, of the same group, to exist. If the degree of pollution for the Sagami $\mathrm{R}$., as measured by the indicators $\mathrm{TVC}, \mathrm{Cl}^{-}$and $\mathrm{PO}_{4}{ }^{3-}$, increases to above the range then, we believe that it will be possible for $V$. cholerae non-O1 to exist and increase and it will always be detectable.

Williams L.A. et al. repoted that when the quantity and frequency of $V$. cholerae non-O1 increased on the coast, reported cases of infection also increased ${ }^{15}$. This implies that if the pollution of the Sagami R. is kept below the regular range then it will be impossible for $V$. choleare non-O1 to exist or increase and cases of human infection will become fewer.

For the Sakai R., the relationship between the isolation of $V$. cholerae non-O1, water quality and the number of bacteria was not clearly defined. But, no matter what the conditions, the rate of isolation was high at all of the locations, so we believe that $V$. cholerae non-O1 is capable of existing like microbial flora.

It is reported that enterotoxins are produced from strains of $V$. cholerae non-O1 isolated from the 
environment ${ }^{16)}$ and, in our suvey, we also isolated the CT strain. The percentage isolated was 5.8\% (4 of the 69 samples) and $13.3 \%$ from the samples with $V$. cholerae non-O1 isolated, which is very low when compared with the rate of isolation of this toxin from Chesapeake Bay') or from the Colorado R. ${ }^{10)}$. Moreover, it is considered that there is little chance of infection from the toxin-producing strain as aquatic foods such as fish and shellfish are not taken from the Sakai R.. On the other hand, for the Sagami R., the possibility of its existence cannot be ignored even though strains exhibiting CT were not detected. Thus if the pollution level increases or, by some change in the envionment, the strain exhibiting CT grows, then we must pay special attention to this as the risk of infection through $V$. cholerae non-O1 will also increase.

From the above, we believe that it is desirable to keep the level of pollution below the regular level as much as possible and to use the indicators $\mathrm{TVC}, \mathrm{Cl}^{-}$, and $\mathrm{PO}_{4}{ }^{3-}$, in order to detect and prevent the growth of V. cholerae non-O1.

\section{Acknoledgements}

The authors are greatly indebted to Mr. Satoru Takaoka, Mr. Toshihiro Ishikawa and Mr. Atsushi Hagiwara (trainees of the Department of Public Health, School of Hygienic Sciences, Kitasato University) for the investigation of the rivers.

The substance of this paper was reported at the conference of the 47th Japanese Society of Public Health (Sapporo).

\section{References}

1) Kenyon, J.E. Gillies, D.C., Piexoto, D.R. \& Austin B.: Vibrio cholerae (non-O1) isolated from California Costal Waters. Appl. Environ. Micorbiol., 46: 1232-1233, 1983.

2) Kaper, J., Lockman, H., Colwell, R.R. \& Joseph, S.W.: Ecology, serology and enterotoxin production of Vibrio cholerae in Chesapeake Bay. Appl. Environ. Microbiol., 37: 91-103, 1979.

3) Pharmaceutical Society of Japan. In Standard Methods of Analysis for Hygienic Chemists, 109-117, Kaneharashuppan, Tokyo, 1980.

4) Educational commitee of Japanese society for bacteriology. In Examination method for Vibrio cholerae and enterotoxigenic Escherichia coli. 9-19, Saikonsha, Tokyo, 1981.

5) Takita, S., Watanabe, K., Maruyama, S. \& Ooi, K.: Pathogenicity and viability of cholerae vibrio isolated from the Mama river, Ichikawa, 1979. Jpn. J. Public Health., 27: 535-542, 1980.

6) Colwell, R.R., Kaper, J. \& Joseph, S.W.: Vibrio cholerae, Vibrio parahaemolyticus, and other vibrios: Occurence and distribution in Chesapeake Bay. Science, 198: 394-396, 1977.

7) Wilson, R., Lieb, S., Robets, A., Stryker, S., Janowski, H., Gunn, R., Riddle, C.F., Barrett, T., Morris, J.G. \& Blake, P.A.: Non-O1 group 1 Vibrio cholerae gastroenteritis associated with eating row oysters. Am. J. Epidemiol., 114: 293-298, 1981.

8) Garay, E., Arnau, A. \& Amano, C.: Incidence of Vibrio cholerae and related Vibrio in a coastal lagoon and seawater influenced by lake discharges along an annual cycle. Appl. Environ. Microbiol., 50: 426-430, 1985.

9) Lin, F-Y.C., Morris, J.G.Jr., Kaper, J.B., Gross, T., Michalski, J., Morrison, C., Libonati, J.P. \& Israel, E.: Persistence of Cholera in the United States: Isolation of Vibrio cholerae $\mathrm{O} 1 \mathrm{from}$ a patient with diarrhea in Maryland. J. Clinic. Microbiol., 46: 1232-1233, 1986.

10) Rhodes, J.B., Smith, H.L.JR. \& Ogg, J.E.: Isolation of non-O1 Vibrio cholerae serovars from surface water in Western Colorado. Appl. Environ. Microbiol., 51: 1216-1219, 1986.

11) Singlton, F.L., Attwell, R., Jangi, S. \& Colwel, R.R.: Effect of temperature and salinity on Vibrio cholerae, Appl. Environ. Microbiol., 44: 1047-1058, 1982.

12) Nishio, T., Kida, M. \& Shimouchi, H.: Experimental observation on vicissitude of enteropathogenic bacteria in river water. Jpn. J. Pubric Health, 18: 717-723, 1971.

13) Hood, M.A. \& Ness, G.E.: Survival of Vibrio cholerae and Escherichia coli in estuaine waters and sediments. Appl. Environ. Microbiol., 43: 578-584, 1982.

14) Fukumi, H.: Cholera. In Karada no kagaku (Popular medicine), 92: 20—25, 1980. 
15) Williams, L.A. \& LaRock, P.A.: Temporal occurence of Vibrio species and Aeromonas hydrophila in estuarine sediments. Appl. Environ. Microbiol., 50: 1490-1495, 1985.

16) Craig, J.P., Yamamoto, K., Takeda, Y. \& Miwatani, T.: Production of Cholera-like enterotoxin by a Vibrio cholerae non-O1 strain isolaed from the environment. Infect. Immunol., 34: 90-97, 1981.

\title{
河川水質と Vibrio cholerae non-O1の検出について
}

\author{
北里大学衛生学部公衆衛生学教室 \\ 内 山秀 和 等々力達也 \\ (平成 1 年 3 月 1 日受付) \\ (平成 1 年 5 月 2 日受理)
}

自然環境から Vibrio cholerae non-O1が検出さ れたといら従来の報告によれば，検出が海水か河 川水などかによって, 検出時の環境の個々の条件 が異なっている。

そこで，2つの河川で河川水質の差異，および 指標細菌の動向を中心に $V$. cholerae non-O1の生 存条件の検討を試みた。

1) $V$. cholerae non-O1は陸上や他の污染地点 からの流入ではなく, 河川のその検出地点での生 存が考学られた。

2）水質污染度の高い河川，あるいは同一河川で
も水質污染度の高い地点ほど $V$. cholerae non-O1 の検出率が高かった。

3）水質污染度の低い河川あるいは水質污染度 の変動の少ない河川で $\mathrm{C} 1$-イオン, リン酸イオン の増加，または普通寒天培地上 $37^{\circ} \mathrm{C} 24$ 時間で集落 を形成する細菌菌数の増加は V. cholerae non-01 の検出度を高めるようである。

4） V. cholerae non-O1の検出させた試料のら ちコレラェンテロトキシン産生菌を含む試料は約 13\%であった。 